\title{
The legitimacy of Dutch do-it-yourself initiatives in Kwale County, Kenya
}

\section{Sara Kinsbergen}

To cite this article: Sara Kinsbergen (2019) The legitimacy of Dutch do-it-yourself initiatives in Kwale County, Kenya, Third World Quarterly, 40:10, 1850-1868, DOI: 10.1080/01436597.2019.1644497

To link to this article: https://doi.org/10.1080/01436597.2019.1644497
(c) 2019 The Author(s). Published by Informa UK Limited, trading as Taylor \& Francis Group.

曲 Published online: 19 Aug 2019.

Submit your article to this journal $\widetilde{ }$

Џلll Article views: 753

Q View related articles $\sqsubset$

View Crossmark data $\asymp$

Citing articles: 1 View citing articles $₫$ 


\title{
The legitimacy of Dutch do-it-yourself initiatives in Kwale County, Kenya
}

\author{
Sara Kinsbergen
}

Anthropology and Development Studies, Radboud University, Nijmegen, The Netherlands

\begin{abstract}
Established development organisations face a long-standing legitimacy crisis for not living up to the expectations once set. Meanwhile, thousands of small-scale, voluntary development organisations - referred to as Private Development Initiatives (PDIs) - have joined the field of international development. In this article, I examine the legitimacy of their acts from a local government perspective based on an analysis of four dimensions of legitimacy: regulatory, pragmatic, normative and cognitive legitimacy. The study took place in May 2017 in the Kenyan coastal county of Kwale. A range of government officials were interviewed on how they perceive the interventions of international development organisations in general, and Dutch PDIs in particular, and on their cooperation with these development actors. The study shows that, although many of these PDIs operate in areas that fall under the responsibility of the local government, most of them have a rather limited cooperation with the local government, putting their legitimacy in the eyes of local government officials at stake.
\end{abstract}

\section{ARTICLE HISTORY}

Received 4 March 2019

Accepted 11 July 2019

\section{KEYWORDS}

Private development initiatives legitimacy local government Kenya

\section{Introduction}

This study is based in Kwale County, the most southern coastal county of Kenya, an area of $8270 \mathrm{~km}^{2}$ and about 650,000 inhabitants. ${ }^{1}$ With the beautiful white, sandy beaches of Diani, Kwale County is one of the top destinations for tourist visiting Kenya. ${ }^{2}$ Diani Beach has been awarded 'Africa's leading beach destination' for the past five years. As a result, the hospitality sector is the number one provider of paid jobs. ${ }^{3}$ Despite the benefits the county derives from being a popular tourist destination, of the 47 counties in Kenya, Kwale County is one of the five most deprived counties in terms of people living below the poverty line and inequality. ${ }^{4}$ Kwale County can count on the support of a very large and diverse group of both national and international development actors in battling poverty, inequality and exclusion. From large-scale bilateral players such as United States Agency for International Development (USAID) and Danish International Development Agency (DANIDA) to small-scale do-it-yourself type of organisations, all of these are active in the county. The composition of the field

CONTACT Sara Kinsbergen s.kinsbergen@maw.ru.nl EAnthropology and Development Studies, Radboud University, Nijmegen, The Netherlands

(c) 2019 The Author(s). Published by Informa UK Limited, trading as Taylor \& Francis Group.

This is an Open Access article distributed under the terms of the Creative Commons Attribution-NonCommercial-NoDerivatives License (http://creativecommons.org/Licenses/by-nc-nd/4.0/), which permits non-commercial re-use, distribution, and reproduction in any medium, provided the original work is properly cited, and is not altered, transformed, or built upon in any way. 
of development actors there forms a perfect reflection of the changing aid architecture and hence allows for studying a new set of research questions this raises.

Kwale County provides an appropriate case study as it demonstrates that the once relatively uncomplicated reality of (inter)governmental agencies and NGOs as main actors in development is challenged by an ever-growing number of a more diverse group of actors entering the field, each with their own motives and modus operandi. This challenges the notion of international development as a community of actors with a shared language, values or standards, and working methods, as described by Develtere. ${ }^{5}$ Besides, new actors contest the existing monopoly of traditional development actors and increasingly turn the development community into an arena characterised by competition for funding, legitimacy and even recipients. ${ }^{6}$ This amalgam of actors brings along a new range of research questions. From the perception of the Global North, where many, but certainly not all, of these new actors originate from, these include questions about the distinctive character and role of these actors, the type of synergies and innovation, if any, resulting from this and donors' responses to competitive funding requests from both established and new actors. ${ }^{7}$

From the perception of the aid receiving countries, questions on relating to and governing of this new aid architecture are very prominent. Studies on proliferation and fragmentation of the field of international development cooperation clearly show that the transaction costs resulting from the increasing number of donor agencies lead to serious, negative consequences for receiving countries. Overlap, duplication and high administration costs involved with managing different working methods, requirements and expectations of different (type of) donors are only some of the consequences. ${ }^{8}$

In this current research, the response of receiving countries towards this diversifying field is central. Specifically, in an exploratory manner, this article focuses on the perceptions of local government authorities in Kwale County with regard to one particular alternative development actor: small-scale, voluntary development organisations, referred to as Private Development Initiatives (PDIs). I focus here in particular on Dutch PDIs operating in the area, building on previous research. ${ }^{9}$ This study aims to get a clear understanding of how local government authorities perceive the work of these organisations, and if, how and why they interact with them. The findings will be analysed from a legitimacy perspective. Starting from an understanding of legitimacy as a'generalized perception [...] that the actions of an entity are desirable, proper or appropriate within a socially constructed system of norms, values, beliefs and definitions, ${ }^{\prime 10}$ this study aims to broaden our understanding of the construct of PDI legitimacy through the eyes of local government officials. ${ }^{11}$ Accordingly, in this analysis, the county government forms the legitimising audience. ${ }^{12}$ I use the models of Lister ${ }^{13}$ and, partly, Ossewaarde et al. ${ }^{14}$ because both stress and incorporate the importance of perspective in their models. In a more or less similar manner, they distinguish between four different dimensions or sources of legitimacy: regulatory, pragmatic, normative and cognitive. Regulatory legitimacy refers to the conformity with regulatory institutions, rules and laws. ${ }^{15}$ Pragmatic legitimacy questions if an organisation conforms to the demands of the legitimising audience; it thus rests on the self-interest of an organisation's audience. ${ }^{16}$ Normative legitimacy deals with congruence between the values pursued by an organisation and wider'societal' values; it is based on a collective account of responsibility for the fate of victims. ${ }^{17}$ Ossewaarde et al. ${ }^{18}$ conclude that mission statements of an international aid agency create a normative source of legitimacy. A final source of legitimacy - cognitive - is based on cognition, referring to 'mental models' of the stakeholders and the agency. It is not just 
'Do we agree with the vision of this agency?' (normative legitimacy), but also'Is this agency "one of us"'? ${ }^{19}$ The question addressed here is what characteristics or behaviours the county government considers when assessing the legitimacy of PDIs. ${ }^{20}$

The background section will first provide a more in-depth understanding of the changing aid architecture with particular attention to PDIs as alternative development actors. This is followed by an introduction to Kwale County in general, and its development situation and development organisations'scenery in particular. Third, the research approach is introduced after which the findings of the study are presented, discussed and concluded.

\section{Research context}

In the past decade, the world of international development has undergone rapid changes, instigated by what is sometimes referred to as the 'triple revolution' ${ }^{21}$ This refers to the emergence of new development goals (global collective action problems such as pandemics, climate change, energy crisis); the rise of new development actors; and the growing number of new development instruments, a trend also referred to as innovative development finance. ${ }^{22}$ This study takes as its starting point the second aspect of the revolution: the increase in number and diversity of players in the field of international development. In academia there is a growing attention for the emergence, role and position of new(ly recognised) actors such as emerging state actors (e.g. China) and more unusual suspects such as celebrity humanitarians and private foundations. ${ }^{23}$ Conventionally, three aid channels are distinguished. First, there is the bilateral aid channel, referring to government-to-government support. Second, the bilateral aid channel refers to intergovernmental organisations such as the World Bank and the UN. Finally, there is the civilateral channel including civil society organisations, most often grouped under the heading of non-governmental organisations (NGOs). Actors in these three channels are seen as 'traditional donors' in the sense that they find 'their raison d'être in international development co-operation' and they essentially form 'one community [...] with a domain-specific set of values and norms, codes of conduct, and their own discourse and vocabulary'. ${ }^{24}$ Interestingly, and indicative of their position in the field of international development, an omnipresent alternative actor in many Northern countries remains largely untouched: the thousands of ordinary individuals who actively engage in the fight against poverty by starting their own small-scale, voluntary development organisation. I refer to these organisations as PDIs.

In recent years, academic interest in this growing group of 'do-it-yourself' type of development organisations is increasing; with each scholar using its own terminology and definition. ${ }^{25}$ The common denominator in this range of definitions is the small-scale (in terms of people involved and budget) and the voluntary character of these groups. With regards to the Netherlands, a PDI is defined as (1) a group of people who (2) give support in a direct way (3) to one or more developing countries. Accordingly, PDIs are not only active in the Netherlands and their task is not limited to (financially) supporting other Dutch development organisations. They offer (4) structural support for organisations, communities or groups of people rather than one-off, individual support. Added to this are three characteristics that clearly distinguish PDIs from established (or traditional) development organisations: PDIs (5) do not receive direct funds from the Ministry of Foreign Affairs, (6) are small in scale and (7) voluntary in character. ${ }^{26}$ Small-scale is defined as having fewer than 
20 regular members, ${ }^{27}$ or an annual budget of less than 1 million euro. The voluntary character is defined on the basis of an upper limit of $20 \%$ or less of paid members in charge of the running of the organisation. ${ }^{28}$ These demarcations are contestable. However, since organisations have to meet all seven criteria mentioned above to be referred to as a PDI, this group of organisations clearly distinguishes itself from more established development organisations or other alternative development actors. ${ }^{29}$

Two surveys among nearly 900 Dutch PDIs ${ }^{30}$ show the following picture: run by, on average, four volunteers, Dutch PDIs spend on average 50,000 euro per year on development projects with a geographical concentration on Africa (e.g. Kenya, Ghana, Uganda) and Asia (e.g. Indonesia, India, Nepal). A large majority (94\%) of PDIs is managed only by volunteers. Most Dutch PDIs are founded or run by older persons ( 55 years of age and above) and established mostly by apparent coincidence after a journey or longer stay in a developing country. For the largest part of their budget, PDIs depend on donations of private donors. ${ }^{31}$

Although PDIs are not a new phenomenon per se, the process of globalisation and economic prosperity in strongly individualised Northern societies has resulted in increased tourism and volunteering opportunities. This is confirmed by the two datasets showing that nearly $45 \%$ of the PDIs are established as a result of a holiday, volunteer work or internships in a developing country. In addition, this is reflected in the popular project countries of PDIs, with most of them being popular, long-haul holiday destinations. ${ }^{32}$ These large-scale macro processes can hence be seen as important push factors for the 'mainstreaming' of the field international development. ${ }^{33}$ Development projects and fundraising plans are designed in living rooms, churches or schools, and executed on a voluntary basis by ordinary citizens. Development cooperation is becoming more and more the task 'of all of us', taking place in everyday life. ${ }^{34} \mathrm{~A}$ process also referred to as democratising development/foreign aid. ${ }^{35}$

However small these individual organisations are, studies' estimates on the (increasing) number of PDIs, the number of people involved and their estimated total budget illustrate that establishing and running a PDI is not anecdotal; they are increasingly present and visible. ${ }^{36}$ For the Netherlands, a 2014 study showed $4 \%$ of the adult population (about half a million) to be actively involved in one (or more) of the several thousands of PDIs. ${ }^{37}$ In 2015, Dutch PDIs received contributions of about 47 million euro from Dutch households. ${ }^{38}$ In England and Wales, there were around 2300 internationally operating charities with a budget up to $£ 100,000$ in 1995 . This number rose to over 10,000 in 2014 , of which nearly half had a budget of $£ 10,000 .{ }^{39}$ A European mapping of PDIs concluded that PDIs 'are common and widespread throughout Europe, but under different labels, in different quantities, and often unknown as a concept or notion of its own'40 In the US, this type of 'do-it-yourself' development is increasingly recognised. Schnable ${ }^{41}$ has shown there to be more than 11,000 registered American relief and development organisations of which nearly 60\% (6600) have an annual budget less than US\$25,000 and hence are presumably run exclusively by volunteers or at least 'bear heavy burdens of voluntary labor'.42

Roughly, PDI studies so far can be grouped in three categories: PDIs' being (mapping, typifying, coming of age), doings (interventions, sustainability, impact, accountability) and relating (with stakeholders such as beneficiaries, other development actors, back-donors). This current study belongs to the third category of studies and does so by focusing on the relations of PDIs with local (i.e. global south) governments. 


\section{PDIs and local government}

The majority of PDIs' development interventions take place at a local (versus national or regional) level and can be characterised as 'service delivery' type of activities, with a large number of projects aiming at children and young people in the area of health care and education. ${ }^{43}$ Therefore, most PDIs intervene in areas that generally (but not exclusively) belong to government jurisdiction. Considering this, cooperation between PDIs and local government authorities would therefore be expected. However, studies so far have found that many PDIs tend to ignore local government authorities. ${ }^{44}$ As concluded by Appe and Telch, most PDIs keep the government 'at arm's length. ${ }^{45}$ In some cases, this is a deliberate act: they do not wish to cooperate with government officials because of their conviction that this involves corruption and unwanted bureaucracy. For others, working with the government is not how their organisation operates; they have not considered this and are not convinced, or even aware, of the possible necessity to do so. A larger group of PDIs maintains a consultative relationship with the local government in the area wherein they operate. They inform civil servants concerned on their presence and plans or request necessary information. In response to the question if they cooperate with the local government, the founder and manager of a Dutch PDI installing solar systems in primary and secondary schools in Western Kenya states:

No. We do make ourselves known to the government. But we do not cooperate with them. If the government asks us something, we will do it. But we are not part of the local development programmes. That is because we do not trust the government. They like what we do, but we do not participate in their programmes. We only inform them on what we did. (Interview PDI founder 2010).

In existing studies, only a smaller group could be traced that actively cooperates with the government, with some PDIs establishing a Memorandum of Understanding with government authorities resulting in jointly designed, implemented and funded programmes and others actively trying to influence government policy.

\section{Kwale County's current status}

The passing of the Kenyan constitution in 2010 was the start of a process of decentralisation, referred to as 'devolution': transferring power and resources to local governments. ${ }^{46}$ Considering this new Kenyan government structure, studying the relation between PDIs and local government authorities becomes particularly pertinent. In the new government constituency, a range of government functions previously belonging to the responsibility of the national government, have been devolved to the 47 counties in the country. ${ }^{47}$ Among these functions are agriculture, health, transport and pre-primary education, village polytechnics, home craft centres and childcare facilities. After the 2013 general elections, the first county governments came into office. One of the first tasks of county governments was drafting a five-year (2013-2017) County Integrated Development Plan (CIDP). This plan, starting from a participatory assessment of the development state of the county, offers an overall framework for development. It aims to co-ordinate the work of both levels of the government in a coherent plan to improve the quality of life for all the people. The plan and budgeting resulted from an extensive, active consultation of the local population. 
Kenyan citizens have the mandate to hold the government accountable and the government is obliged to report, both on short- and long-term results, to its citizens. ${ }^{48} \mathrm{Kwale}$ County published its first CIDP in 2013 (2013-2017) and second in 2018 (2018-2022). ${ }^{49}$

Both of these CIDPs, and data of the Kenyan Bureau of Statistics, show that Kwale County faces considerable challenges in terms of socio-economic development of its population. Despite the revenues Kwale County receives via tourism, Kwale is still one of the more deprived of the 47 counties of Kenya: $71 \%$ of the population of Kwale County lives below the poverty line compared to $45.9 \%$ of the Kenyan population. Moreover, in terms of employment, education, water and sanitation, the living conditions of Kwale's inhabitants are worse compared to other counties..$^{50}$ In her historical account, Berman explains in great detail how the coastline of Kwale County, in particular the village of Diani, became an important tourism destination, with Germany in particular heavily investing in tourism infrastructure from the early 1960s onwards. Two main reasons can be distilled explaining why this did not result in a more prosperous state of the county and its population. First, as Berman explains, during the 1980s and 1990s 'building boom', (illegal) land transactions were the order of the day in the Diani area, leaving many local villagers, mainly Digo, landless. As a result, the large influx of tourist did not so much result in increased living standards for the local population, but in a more deprived position..$^{51}$ Currently, most hotels are owned and/or managed by foreigners or upcountry Kenyans, meaning a large part of the revenue leaves the county. ${ }^{52}$ Second, the hospitality sector caters for the largest part of household income stemming from wage earnings. However, wage earnings make up only $8.6 \%$ of the average household income. ${ }^{53}$ So only a small part of the county's population directly benefits from incomes generated through tourism.

Whereas unequal distribution of revenues stemming from tourism cannot be referred to as the single origin of Kwale County's present-day situation, it is against this background one should understand the current situation of the county, the challenges the county government is confronted with and the (potential) role development actors can take up in Kwale.

\section{Kwale County and the development architecture}

Available government resources are inadequate for achieving the goals set in the CIDP but Kwale County is home to a large and very diverse group of international development actors bringing in large amounts of extra resources. ${ }^{54}$ An exhaustive overview of players, their budget and areas of intervention is not available. Nevertheless, Table 1 gives a snapshot of the range of development actors which this current study came across. These are actors that are currently working in the county, or have done so in the recent past. This mapping, as is the study, focused on international development agencies. This overview shows that all different types of development actors are present in the county.

What is particularly striking in the mapping of Kwale County's development scenery is the high density of PDIs operating in Kwale County. This is a direct result of Kwale being a popular tourist destination, with many of these tourists starting their own foundation in the aftermath of their visit. ${ }^{55}$ In countries located in what is currently referred to or perceived as the Global South, being a tourism hotspot (countries, regions or towns) often coincides 
Table 1. Overview of development scenery Kwale County.

\begin{tabular}{|c|c|c|c|}
\hline Bilateral & Multilateral & Civilateral & Philanteral \\
\hline DANIDA (Denmark) & World Bank & Plan International & Agha Khan Foundation \\
\hline USAID (USA) & IOM & Red Cross International & Base Titanium \\
\hline GIZ (Germany) & UNDP & $\mathrm{ACT}$ International & $\begin{array}{l}\text { Several hundreds of PDIs } \\
\text { from different } \\
\text { nationalities (e.g. } \\
\text { Belgium, Germany, } \\
\text { UK, the Netherlands) }\end{array}$ \\
\hline $\begin{array}{l}\text { EU (European } \\
\text { Development Fund) }\end{array}$ & Global Environment Facility & WWF & \\
\hline FORMIN (Finland) & & Search for Common Ground & \\
\hline SIDA (Sweden) & & Agha Khan Foundation & \\
\hline
\end{tabular}

Source: Interviews Kwale 2017, complemented with web-based search.

with a high density of PDI activity. Examples of this are Gambia, Bali (Indonesia), Moshi (Tanzania), Cape Coast (Ghana), Cusco (Peru) and Antigua (Guatemala). ${ }^{56}$ Kwale County forms no exception to this rule. In Germans on the Kenyan Coast, Berman describes how interwoven the areas of development ('charity' in her account) and tourism are in Kwale County. She describes how'many tourist [...] feel compelled to improve the living conditions of African Kenyans and engage in humanitarian aid activities. ${ }^{\prime 7}$ An expat living in Kwale County and involved in a charity himself explains the large number of visitors getting involved in a PDI:

they [tourists] spend ten days in an all-in resort. At the end of their stay, they feel the need to go out and visit an orphanage or a school. They buy some pens or candies for the kids as a way to buy off their guilt. (Informal conversation founder PDI)

Establishing and developing relations with this large and diverse group of development actors is clearly work in progress for the government of Kwale. This can be seen from a comparison of the first and second CIDP. In the first CIDP, the section'resource mobilisation' does not explicitly mention civil society actors as partners bringing in resources that can be deployed in reaching government plans. ${ }^{58}$ Interestingly, the second CIDP does mention 'non-state actors' as stakeholders in achieving the county goals. The documents states that 'they [non-state actors] will be encouraged to invest in governance and development sectors of choice especially on capacity building of county governance structures and communities they work with'.59 'The following roles for non-state actors are being distinguished: play a critical role in supporting policy formulation processes, financing projects and programmes, providing civic education to the citizenry, providing watchdog roles, conducting or supporting surveys and researches and development as well as supporting resource mobilization activities'.60

Achieving this type of cooperation requires, first, that the government is aware of the presence and activities of these external development actors, and second, that such awareness can be translated into forms of coordination and alignment between the local government and the different external actors involved in development in the county. It is a challenging endeavour for the fairly young Kwale County government to ensure that this large in number and strongly diverse group of development actors contribute to reaching the CIDP and benefit the population of Kwale County. 


\section{Research approach}

This exploratory study took place in May 2017 in the southern coastal county of Kwale County, Kenya. This site was selected because of its high concentration of development organisations in general and PDIs in particular. ${ }^{61}$ First, I undertook a web-based mapping of Dutch PDIs operating in Kwale, including an overview of the main characteristics of these organisations. This allowed for obtaining a clear understanding of the presence of PDIs in the county. Their intervention areas, both thematic and geographical, the size of the organisations and historical origins were included in the mapping. Second, I carried out interviews with county government officials of different departments. Departments were chosen in accordance to the thematic orientation of PDIs including health and education. Interviewees were selected based on their function and role within the department. All were in positions where cooperation with development organisations would have been part of their role. Nine interviews took place with different ministers, directors and chief officers. By talking to different officials within one department, it aimed to get a comprehensive understanding of the relations between the government and PDIs. In the interviews with government officials, I focused on aspects of awareness, including if government officials were aware of or familiar with the presence of PDIs operating in Kwale County, and their possible cooperation and perceptions, that is, how government officials perceive the activities of PDIs and their relations with the county government. Although the focus of this study is on PDIs, conversations also turned to other, more established, development actors. This resulted in some, although tentative, comparisons of how PDIs relate to the county government and how established development actors do so. ${ }^{62}$

These interviews were complemented with analyses of government policy documents and interviews with three local small NGOs and one large NGO. In addition, this study builds on previous, qualitative and quantitative research on PDIs that included, among others, work done in Kwale County. All names of respondents and ministries have been anonymised to protect confidentiality.

\section{Findings}

The web-based mapping of Dutch PDIs operating in Kwale County resulted in an overview of 49 organisation currently operating in the area, as well as those that have been active in the recent past. These organisations were established in the period 1992-2017, and on average they have been working in the county for 11 years. Figure 1 illustrates the increase of Dutch PDIs working in Kwale. A large number $(n=32)$ of these organisations intervene in the area of education, with over half also supporting projects with a different thematic orientation (such as health care). Twelve PDIs have a health care focus. A smaller number supports shelters for children and youngsters, income generating activities and water and sanitation projects. The mapping provides information of the 2016 annual budget of 30 of the organisations. Their annual budgets range from 2300 euro to 260,000 euro. The total annual budget of these organisations amounts to 1,669,420 million euro in 2016 . This means that together these 30 PDIs spend on average 2.5 euro per inhabitant of Kwale County. This budget equals $12 \%$ of the government's budget for health care and education in that same period. ${ }^{63}$ All of the PDIs involved in the study operate in areas that fall under responsibility of the county government, and hence cooperation with the county government would be 


\section{Number of Dutch PDIs in Kwale County}

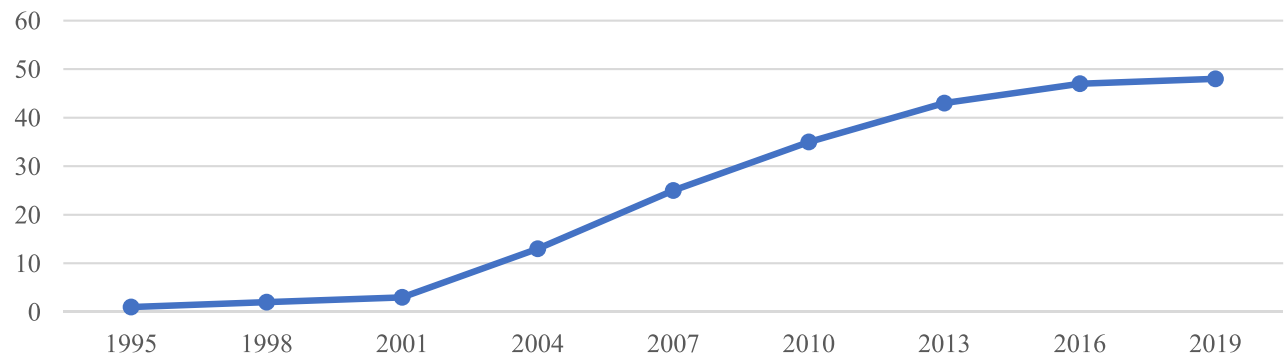

Figure 1. Number of Dutch PDIs in Kwale County. Source: Kinsbergen, PDI Database Kwale County 2017 [Datafile].

expected. For this reason, cooperation between PDIs and the county government is central to the study. For some of the PDIs it accounts that certain aspects of their work belong to the jurisdiction of the national government instead of the county government. However, considering the feasibility of the study, this cooperation is not included in the current study.

\section{Awareness and cooperation}

All interviewees were asked to list development actors they were aware of operating in Kwale County. While this resulted in a comprehensive mapping of the more established actors from the bi- and multilateral aid channel and more established NGOs, the number of PDIs mentioned by the interviewees, and in particular Dutch PDIs, did not reflect their actual number. From all the Dutch PDIs included in the mapping, only four of them were mentioned spontaneously. Whereas this might not be surprising considering the large number of small-scale organisations operating in the area, many of the organisations have a long track record and have been bringing in a considerable amount of money over the years. One could expect this to result in a certain level of awareness on the side of the government, or in cooperation between PDIs and the county government.

Interviewees' estimates on the number of development actors deliberately working within the framework of the CIDP range from 30-40\%, with the exception of one interviewee who expected $70 \%$ are doing so. Government officials felt that many smaller organisations work their way around the local government. One of the interviewees recalled an organisation that had been working for 15 years in the area before coming to the attention of county officials. The method of working of a large majority of the PDIs could be described as taking place 'under the government radar'.

Most bi- and multilateral agencies and part of the established NGOs enter the county through the national government level. The national government in its turn refers these organisations to the county government. PDIs cooperating with the county government approach the government directly or do so via the sub-county level. Experiences from government officials show that the government's room to manoeuvre within the plans of international development agencies varies. The overall experience of government officials is that agencies entering government offices 'have their plan, they come to share' (Interview civil servant I). Informing is, according to most of the interviewees, an important reason for many agencies to make contact with local government offices. Several interviewees stress that 
often plans are already designed and budgets drafted before they approach the responsible department. In these cases, meeting with government officials appears as a formality they have to go through:

They come to inform what and where they are planning programmes. They do not really come to ask for approval, they are just informing. (Interview civil servant II)

Although government officials are not of the impression that these agencies are actually asking for permission, some of them come in 'for a signature, to get their funding' (Interview civil servant I). Many institutional donors of these agencies request a formal document including a government signature as a proof of consent by the local government. While the number of PDIs mentioned is small, government officials have experience in cooperating with a number of them. Occasionally, more intensive cooperation takes place between county governments and PDIs. In these accounts, the overall process is as follows: a PDI approaches the government presenting their general plan and preferred working area. In response to this, the government representative brings in the plans of the county government or a specific department. Through discussion both parties look for synergies, draft a joint plan and share responsibilities. Several examples were given by government officials of more established development actors that ceased their activities or changed their plans in response to the new government structure, plans and corresponding roles for development actors:

Before devolution, the county government had no resources to do so [service delivery]. Now they have. Therefore, some of the NGOs started to revise their strategic plan based on the new constitution. They became more active in the field of governance, capacity building of communities to take up their roles within the new constitution. (Interview civil servant III)

The second CIDP of Kwale County shows that when development actors are being included as (potential) partners in the government planning, it concerns mainly bi-, multi- and civilateral actors. No mention has been made of PDIs neither in the planning nor in the budgeting. ${ }^{64}$

\section{Response of government}

The above shows that overall the cooperation between county government and PDIs is limited. The response of government officials towards the seemingly evasive approach of PDIs could be best described as pragmatic: as one informant put it: 'what can we do about it?' (Interview civil servant III). Overall, three lines of reasoning could be distinguished in their responses. First, to a large extent, the government understands the reticence of development actors in general, and PDIs in particular, in cooperating with county government. They are aware of the bureaucratic image of the government and realise this is a reason for many organisations to avoid any form of cooperation or to restrict cooperation to informing responsible authorities on their plans.

Second, several interviewees feel that international agencies in general, and PDIs in particular, need to get used to the new Kenyan government structure. The devolvement of government functions to county level is not yet completely clear to all agencies. Current government structures and officials involved are still relatively new, so finding their way can be challenging. At the same time, they are confident that with time comes understanding and acceptance of the new structure from the side of (international) aid agencies. In 
addition, there is hope that the new government structure will bring an end to dominant notions of government authorities being corrupt, bureaucratic and thereby a partner to be avoided.

Finally, among the government officials there is awareness of and understanding for the agenda-setting reality of foreign development agencies which limits the room to manoeuvre for county government within the plans. As one of the interviewees mentioned, 'They [the organisations] have their mandate' (Interview civil servant V), determining their thematic orientation and regional focus. Therefore, he understands that at the moment when development agencies enter government offices, agencies' programs and projects are often already determined and not always (directly) support governments policy and plans. Another interviewee pointed to the strong influence of institutional donors who, in their home countries, influence the agenda, plans and budget of agencies. He referred to this as 'the long arm of the donor' (Interview civil servant V), resulting in a preference for programmes and projects that allow for 'quick wins'. He reflected on this by saying, with a shrugging of the shoulders: 'if you cannot beat the system' (Interview civil servant V).

Although there is understanding among government officials for a tendency among PDIs to avoid or limit their cooperation with county government authorities, in discussion it clearly emerged that they are convinced of the need for a closer cooperation. As one of the interviewees stated: 'You cannot just walk in and do what you want' (Interview civil servant VI).

This conviction comes not so much from a legal perspective. At the time of our study, the legal framework of the Public Benefit Organizations (PBO) Act in Kenya was under construction. Therefore, rules of engagement and the assignment of enforcement responsibility still had to be determined. Questions on what are the rules of engagement and what can hence be defined as 'legal' or 'illegal' operations of international aid agencies are open to discussion. Reflecting on the legal framework in the making, the respondents were not keen on drafting a framework with a strong focus on controlling and restricting, with the county government taking up the role of prefect. In addition, with the exception of one interviewee, none of them was in favour of budget support.

The urge of local government officials to enhance cooperation between PDIs and county government was strongly instigated from a development point of view. They aimed for a cooperation with all different stakeholders joining forces to reach the ambitious goals set in the CIDP. They highlighted several important downsides and consequences of non-existent or limited cooperation. Duplication and overlap where mentioned most frequently as negative consequences from a lack of cooperation. Not only did the interviewees consider this to result in inefficient and ineffective use of resources, but also in what they called 'community fatigue', due to the variety of actors operating in the same area, targeting the same people. In order to'supplement the county [... ] it is so good to consult' (Interview civil servant IV). Further, there is a conviction that synergies based on different competences can only come about when cooperation takes place. As one civil servant mentions: 'There are clear areas where NGOs would do better than the government.' He mentions strengthening governance structures, capacity building and accountability. In addition, he states that 'There are clear areas where government is better than NGOs, such as infrastructure'. Therefore, agencies should 'Identify and chose and fill the gaps. Building on the assessment from the government.' Finally, government officials mentioned several other roles they could undertake when cooperating. They could protect international agencies from local actors with suspicious reputation. It would allow them to advise and, where possible, co-finance. 
And although not considered as their primary role, it would also allow them to control what type of interventions where supported or implemented, where and by whom. One of the interviewees sums up the importance of cooperation stating that it'increases the legitimacy, credibility and trust of an organisation'.

\section{Perception}

Despite the strong belief of government officials in the importance of more intense cooperation between PDIs and the county government, and the finding that for a large number of PDIs this is limited, overall government officials are broadly positively inclined towards their presence. When reflecting on a potential exodus of PDIs working in Kwale, one interviewee responded: 'this deficit would not be easily filled. We do not pray for that'. This is confirmed by a civil servant from a different department who says 'Investments in [this department] are expensive. If they would leave, it would have a huge negative impact. The government does not have the capacity to take over'. Thus, although many of these PDIs do not directly align their interventions with the CIDP, there is a conviction that 'what they are doing is not irrelevant' (Interview civil servant VI). The needs of the local population are high, as several of the interviews mentioned, resulting in an overall pragmatic approach towards those bypassing government authorities or those approaching governments with plans that do not allow much room for alignment with government policy.

When talking with government officials on their relations with international agencies in general and PDIs in particular, this pragmatic approach is very apparent. Although formally in power, it feels as if the government is 'being governed' in part by the development actors. When questioned how they experience this and how it affects their operations, it becomes clear it frustrates them. Interviews with other, national and international, organisations painted Kwale County government as an ambitious, progressive government, committed to fully take up its role as a new government and determined to bring an end to perceptions of the government as being autocratic, bureaucratic and corrupt. They are concerned by the deprived situation of the county and dedicated to, through the CIDP, improve the living conditions of the population. For this purpose, they feel that strong ties with both national and international development agencies are required. Being confronted with many actors avoiding this cooperation is experienced as a serious challenge to the county government. When discussing this with the government official who was most outspoken on his feelings of frustration, he asked me whether I was a Christian. Without awaiting my response, he followed:'The Integrated Development Plan [CIDP] is our Bible, when working here, your first priority should be the CIDP' (Interview civil servant II). He stressed the participatory consultation on which the CIDP is based, emphasising that the CIDP is not just a plan from the government, but a plan from the people of Kwale. He summarised his feeling saying: 'people, we survive with them'. This reaction is in line with the pragmatic response described above. A different type of cooperation between the county government and the much-needed development organisations is preferred by government officials. However, their overall feeling is that not much can practically be done to achieve this, and a pathway of enforcement is not considered desirable. 


\section{Legitimacy of PDIs}

These findings allow for an initial analysis of the legitimacy of PDIs through the eyes of the government of Kwale County. As explained above, the question is what characteristics or behaviours does the county government consider when assessing the legitimacy of PDIs? ${ }^{65}$ Following Lister ${ }^{66}$ and Ossewaarde et al., ${ }^{67}$ four dimensions are being distinguished: regulatory, pragmatic, normative and cognitive. I will discuss the different sources of legitimacy in turn. The study shows that adherence to rules and regulations by PDIs was of less importance to the civil servants interviewed. Only members of the health department labelled certain interventions by PDIs firmly as, in their terms, 'illegal', such as distributing medicines with no medical professionals being involved. Lister ${ }^{68}$ emphasises the dynamic character of legitimacy, with legitimacy of an actor variable over time through changes in the context and in the organisation. Considering that the PBO Act in Kenya is still under construction (at time of writing), the question is if in the near future regulatory legitimacy might gain importance, once the rules and regulations for international aid agencies are set.

All interviewees conclude that, from a normative and pragmatic point of view, PDIs can be considered to be a legitimate player. The demands in Kwale County are huge and diverse. Subsequently, values and missions of PDIs directly respond to the goals of the county government, relating to the normative dimension of legitimacy. In addition, because of the high needs, most interventions of PDIs target one or more areas that are of interest to the county government as well, referring to the pragmatic dimension of legitimacy. However, at the same time respondents underline that bypassing the county government implies the risk that interventions do not align with the priorities set in the CIDP, such as in terms of geographical and thematic focus, and type of interventions, and might even disturb government strategies. It does not allow for creating direct synergies between government plans and those of PDIs. In terms of pragmatic legitimacy, from the county governments' perception, a lot can be gained by starting or intensifying the cooperation between PDIs and government authorities.

The final source of legitimacy - cognitive - brings us to an interesting aspect of the legitimacy of PDIs. It becomes very apparent in this study that many PDIs are unknown to county government authorities. As described above, previous studies found that this is because some PDIs, deliberately or not, avoid the local government. ${ }^{69}$ This study shows that lack of or limited cooperation between both is also caused by local government authorities not being aware of or identifying PDIs as part of Kwale's civil society community and thus as serious negotiating partners. This becomes apparent from the stakeholders' meetings held by some of the departments. Although a very small number of PDIs or their local counterparts were invited to and participate in the meetings, the majority are not targeted as potential contributors. Currently, these departmental meetings, also at county level, seem to be largely reserved for established development actors which the county government is familiar with. These are bi- and multilateral aid agencies which offer the county large budgets. For those PDIs and their local counterparts looking for sustainable ways of cooperating with the county government and other stakeholders in Kwale, this was a difficult, somewhat disappointing, experience. One can question if it is feasible and desirable to include the broad spectrum of development agencies in government consultation processes. At the same time, considering that the government budget is not sufficient to address the challenges identified in the CIDP, an open approach towards different types of, often smaller scale, unknown actors might be worth pursuing. 
The coincidence of the government's pragmatic response and feelings of frustration brings us to the essence of the power play typical to aid giver-recipient relations. When needs are high and resources are not sufficient, how much room is there for governments to implement a different set of 'rules of engagement'? This might be particularly challenging in relations between PDIs and government officials in areas such as Kwale, were PDIs are not only resourceful as being 'givers of aid' but also as 'tourists'.

\section{Conclusions}

The findings show that aligning the plans and budgets of international aid agencies operating in Kwale into its CIDP is a challenging task. The high number and diversity of actors makes this a complex process. This turns out to be especially challenging when it concerns PDIs. Most of these small-scale voluntary development organisations operating in Kwale have limited relations with the county government. Whereas more established development actors are more likely to follow the formal routes, entering the county via the national government, many PDIs start working directly with their local counterparts. Although room for negotiating the plans of bi-, multilateral and established NGOs is limited at times, they make themselves and their plans known to the county government. This allows the government to, at least, take these plans into consideration when designing or implementing their own plans, minimising risks of duplication and overlap.

For PDIs, this working manner it is not self-evident. ${ }^{70}$ First, PDIs might not see the added value in cooperating with the local government since many of them have been able to carry out their work without or with only limited cooperation. In addition, discussion with PDIs often show there is the fear that cooperation with the local government requires knowledge, skills and resources they might not possess. For those PDIs that look for cooperation with the county, there is the struggle of being acknowledged as a legitimate actor in the field. PDIs entering government authorities' offices are mostly unknown players to government officials. This is in contrast to, for example, the World Bank and Plan International. When PDIs arrive with small grants and are ignorant of appropriate channels and procedures, they might be considered 'illegitimate' in the eyes of the county government.

In conclusion, there is an interesting tension between the different sources of legitimacy of PDIs. In order for PDIs to gain in terms of pragmatic and normative legitimacy, they would have to invest in close cooperation with the county government and align their interventions consciously with the CIDP of Kwale County. But in order to do so, they would have to be recognised as a serious partner. The mapping from which this study starts can be helpful for the county government in identifying PDIs as an actual actor in Kwale's civil society landscape. Individually, these organisations might be small in size, but as a group they bring in a significant amount of resources to the county. At the same time, individual PDIs and PDIs as a group might want to position themselves and their operation as part of a broader picture and development agenda, acknowledging that in order to implement their individual missions, cooperation with the county government is a beneficial. By doing so, PDIs would gain in terms of cognitive legitimacy. Obviously, all this starts with PDIs operating in Kwale County to make themselves known to the county government. A regulatory framework that requests international aid agencies to register at county level could contribute to this. 
In order for synergies to come about, government authorities should acknowledge PDIs as a serious stakeholder that can contribute to achieving the counties goal. PDIs, on the other hand, have to consider themselves as part of a larger community with government cooperation being a requirement.

This raises the question if PDIs are willing to intensify cooperation with the county government. How are their interests being served by staying under the legitimacy radar? Conversely, what do they stand to lose by giving up this position? And how does their 'coming-of-age' affect their interactions with government officials? To broaden our understanding, a follow-up research will take place closely studying the cooperation between PDIs and (local) government authorities in order to understand mechanism inhibiting, stimulating or facilitating cooperation.

\section{Disclosure statement}

No potential conflict of interest was reported by the author.

\section{Acknowledgment}

I thank Manouk Overkamp for her great support as my research assistant during fieldwork.

\section{Funding}

Funding has been provided by Wilde Ganzen Foundation.

\section{Notes on contributor}

Sara Kinsbergen, a researcher at Radboud University, has studied small-scale, voluntary development organisations since 2007. She wrote her doctoral thesis on these Private Development Initiatives: Behind the Pictures. Understanding Private Development Initiatives (2014). This was the first large-scale, in-depth study on this alternative development actor. She is continuing this study in a three-year research project: The Coming of Age of Private Development Initiatives. In this study, she will focus on how these organisations and their development projects develop over time.

\section{Notes}

1. Kwale County Integrated Development Plan 2018-2022, 14.

2. Worldtravelawards https://www.worldtravelawards.com/

3. County Government of Kwale, First County Integrated Development Plan 2013.

4. Kenya National Bureau of Statistics and Society for International Development, Exploring Kenya's Inequality, VI.

5. Develtere, How Do We Help? 78.

6. Ibid., 12, 39.

7. Kinsbergen and Tolsma, "Explaining Monetary Donations," 1572.

8. Schulpen et al., "Worse than Expected?" 322.

9. Kinsbergen and Plaisier, Is Small Beautiful?; Kinsbergen et al.,"Understanding the Sustainability."

10. Suchman, "Managing Legitimacy," 574.

11. In order to get a comprehensive understanding of the legitimacy of PDIs, perspectives of other stakeholders, such as beneficiaries and other type of development agencies, are of great value 
as well. However, in this current study, the perception of government officials is central to the analysis. As will be explained below, most interventions of PDIs belong to government jurisdiction. Therefore, studying PDI-government relations is of great importance and, so far, received little academic attention.

12. Lister, "NGO Legitimacy Technical Issue," 179.

13. Ibid., 180-1.

14. Ossewaarde et al., "Dynamics of NGO Legitimacy," 43-5.

15. See note 12 above.

16. See note 12 above.

17. Ossewaarde et al., "Dynamics of NGO Legitimacy," 44; Lister, "NGO Legitimacy Technical Issue," 179.

18. Lister, "NGO Legitimacy Technical Issue," 45.

19. Ibid., 182.

20. Ibid., 179.

21. Severino and Ray, "The End of ODA," 1.

22. Ibid., 8 .

23. Schulpen et al., "Worse than Expected?" 323-6; Richey and Ponte, "New Actors and Alliances," 5-7; Dreher and Fuchs, "Rogue Aid?"

24. Develtere and De Bruyn, "Emergence of a Fourth Pillar," 913.

25. A selection of publications on PDIs: Develtere and De Bruyn, "Emergence of a Fourth Pillar"; Kinsbergen, Behind the Pictures; Schnable, "New American Relief and Development Organizations"; Fechter, "Brokering Transnational Flows of Care"; Appe and Telch, "Grassroot International NGOs"; Clifford, "International Charitable Connections."

26. Kinsbergen, Behind the Pictures, 57.

27. 'Member' refers to both paid and non-paid core members.

28. The demarcation of 'small-scale' and 'voluntary' is based on a comparison of organisations within the CIDIN PDI Database meeting up to criteria 1-5 with NGOs in the Netherlands (IS Academie NGO Database). Since organisations have to meet all seven criteria to be included in the study, the database includes organisations that are clearly distinguishable from more established development organisations. For example: those (rare) cases with a budget (close to) 1 million euro had to meet the voluntary criteria as well in order to be included.

29. This definition was formulated in the first large-scale academic study on PDIs and is applied since then in new studies. Dutch organisations involved in the support of PDIs make use of this definition, sometimes in a slightly adapted way. Kinsbergen, Behind the Pictures, 57.

30. CIDIN-PDI Database 2008-2009; Kinsbergen PDI Database 2017.

31. Kinsbergen and Schulpen, "Taking Stock of PIs," 166-7; Kinsbergen, Unfold Private Development Initiatives.

32. Kinsbergen, Unfold Private Development Initiatives.

33. Develtere, How Do We Help? 40; Kinsbergen, Unfold Private Development Initiatives, 39-43.

34. Develtere, How Do We Help? 183.

35. Desai and Kharas, "Democratizing Foreign Aid," 1112.

36. Plaisier and Schulpen, Mondiaal Burger Daar en Hier, 12; Mevis, Een Snapshot Van de Vierde Pijler, 1-3; Bekkers et al., Geven in Nederland 2017; Clifford, "International Charitable Connections," 458-60; Schnable, “New American Relief and Development Organizations," 313-14.

37. Plaisier and Schulpen, Mondiaal Burger Daar en Hier, 12.

38. Bekkers et al., Geven in Nederland 2017.

39. Clifford, "International Charitable Connections," 460-1.

40. Pollet et al., The Accidental Aid Worker, 36.

41. Schnable, "New American Relief and Development Organizations," 313-14.

42. Ibid.

43. De Bruyn, "New Development Philanthropists?" 41; Kinsbergen et al., "Understanding the Sustainability," 230-1; Kinsbergen PDI Database 2017; Schnable, "The Era of Do-It-Yourself Aid," 5.

44. Kinsbergen, Behind the Pictures, 137; Schulpen, Development in "Africa for Beginners," 43-4.

45. Appe and Telch, "Grassroots International NGOs," 12. 
46. See Murunga et al., Kenya, The Struggle, for a detailed reflection on and discussion of Kenya's new constitutional order.

47. Khaunya et al., "Devolved Governance in Kenya," 27-8.

48. Council of Governors, County Integrated Development Plans.

49. County Government of Kwale, First County Integrated Development Plan 2013; Kwale County Integrated Development Plan 2018-2022.

50. Kenya National Bureau of Statistics and Society for International Development, Exploring Kenya's Inequality, VI.

51. Berman, Germans on the Kenyan Coast, 55.

52. Ibid., 183-5, Table 2.

53. Kwale County Integrated Development Plan 2018-2022, 19.

54. Kwale County Budget 2018-2019 shows that $64 \%$ of the annual expenditures of the government are covered by contributions of the national government and own revenues; $25 \%$ is covered through support of multiple bi- and multilateral development actors. County Government of Kwale, Annual Development Plan FY 2018-2019.

55. Berman, "Contemporary German MONGOs," 320-32.

56. Although there is a concentration of PDls working in tourism destinations, a large number of PDIs also work outside these areas, in countries, regions or villages not (often) frequented by tourists.

57. Berman, Germans on the Kenyan Coast, 12.

58. County Government of Kwale, First County Integrated Development Plan 2013, 66-76.

59. Kwale County Integrated Development Plan 2018-2022, 212.

60. Ibid. Italics inserted by present author.

61. Berman, "Contemporary German MONGOs," 320-34.

62. Since the term 'Private Development Initiative' is not familiar to the interviewees and since there are not always clear distinctions between different type of development agencies, I distinguished especially between smaller scale organisations and larger scale organisations.

63. Own calculations based on Kinsbergen, PDI Database Kwale County 2019 [Datafile] and County Government of Kwale County Treasury, Annual Development Plan 2016-2017.

64. Kwale County Integrated Development Plan 2018-2022, 212, 217; County Government of Kwale, Annual Development Plan FY 2017-2018.

65. Lister, "NGO Legitimacy Technical Issue," 179.

66. Ibid.

67. Ossewaarde et al., "Dynamics of NGO Legitimacy," 43-5.

68. Lister, "NGO Legitimacy Technical Issue," 187.

69. Berman, "Contemporary German MONGOs," 235-6; Kinsbergen, Behind the Pictures,137; Schulpen, Development in "Africa for Beginners," 43-4; Appe and Telch, "Grassroots International NGOs," 12.

70. Ibid.

\section{Bibliography}

Appe, Susan, and Fabian Telch. “Grassroots International NGOs: Using Comparative Interpretive Policy Analysis to Understand Meanings in Private Development Aid." Journal of Comparative Policy Analysis (2019). doi:10.1080/13876988.2019.1582885.

Bekkers, René, Theo Schuyt and Barbara Gouwenberg, eds. Geven in Nederland 2017. Amsterdam: Walburgpers, 2017.

Berman, Nina. "Contemporary German MONGOs in Diani, Kenya: Two Approaches to Humanitarian Aid." In German Philanthropy in Transatlantic Perspective. Perceptions, Exchanges and Transfers since the Early Twentieth Century, edited by Gregory R. Witkowski and Arnd Bauerkämper, 227-243. Cham: Springer, 2016.

Berman, Nina. Germans on the Kenyan Coast. Land, Charity and Romance. Bloomington and Indianapolis: Indiana University Press, 2017.

CIDIN-PDI Database 2008-2009 [Datafile]. 
Clifford, David. "International Charitable Connections: The Growth in Number, and the Countries of Operation, of English and Welsh Charities Working Overseas." Journal of Social Policy 45, no. 3 (2016): 453-486. doi:10.1017/S0047279416000076.

Council of Governors. County Integrated Development Plans. http://cog.go.ke/about-us/20-thecouncil-of-governors/484-county-integrated-development-plans.

County Government of Kwale County Treasury. Annual Development Plan 2016-2017.

County Government of Kwale County Treasury. Annual Development Plan FY 2018-2019.

County Government of Kwale. First County Integrated Development Plan 2013.

De Bruyn, Tom. "New Development Philanthropists? The Effects and Characteristics of the (Flemish) Fourth Pillar of Development Cooperation." Mondes en Développement 161, no. 1 (2013): 33-47. doi:10.3917/med.161.0033.

Desai, Raj M, and Homi Kharas. "Democratizing Foreign Aid: online Philanthropy and International Development Assistance." International Law and Politics 42, no. 4 (2010): 1111-1142.

Develtere, Patrick, and Tom De Bruyn. "The Emergence of a Fourth Pillar in Development Aid." Development in Practice 19, no. 7 (2009): 912-922. doi:10.1080/09614520903122378.

Develtere, Patrick. How Do We Help? the Free Market in Development Aid. Leuven: University Press, 2012.

Dreher, Axel and Andreas Fuchs. "Rogue Aid? The Determinants of China's Aid Allocation." CESifo Working Paper Series No. 3581, 2011.

Fechter, Anne-Meike. "Brokering Transnational Flows of Care: The Case of Citizen Aid." Ethnos (2019). doi:10.1080/00141844.2018.1543339.

Kenya National Bureau of Statistics and Society for International Development. Exploring Kenya's Inequality. Pulling apart or pooling together? 2013.

Khaunya, Mukabi Fredrick, Barasa Peter Wawire, and Viola Chepng'eno. "Devolved Governance in Kenya; Is It a False Start in Democratic Decentralization for Development?" International Journal of Economics, Finance and Management 4, no.1 (2015): 27-37.

Kinsbergen, Sara. PDI Database 2017 [Datafile].

Kinsbergen, Sara. PDI Database Kwale County 2019 [Datafile].

Kinsbergen, Sara and Lau Schulpen. 2011. "Taking Stock of PIs: The what, why, and how of private initiatives in development." In The Netherlands Yearbook on International Cooperation, edited by Paul Hoebink, 161-186. Assen: Van Gorcum.

Kinsbergen, Sara, and Christine Plaisier. Is Small Beautiful? a Sustainability Study of Development Interventions co-Financed by the Wild Geese Foundation. Radboud University, 2015.

Kinsbergen, Sara, and Jochem Tolsma. "Explaining Monetary Donations to International Development Organisations: A Factorial Survey Approach." Social Science Research 42, no. 6 (2013): 1571-1586. doi:10.1016/j.ssresearch.2013.06.011.

Kinsbergen, Sara, Lau Schulpen, and Ruerd Ruben. "Understanding the Sustainability of Private Development Initiatives: What Kind of Difference Do They Make?" Forum for Development Studies 44, no. 2 (2017): 223-248.

Kinsbergen, Sara. Behind the Pictures. Understanding Private Development Initiatives. Nijmegen: Radboud University, 2014.

Kinsbergen, Sara. Unfold Private Development Initiatives. Nijmegen: Radboud University, 2017.

Kwale County Economic Planning Division. Kwale County Annual Development Plan FY 2017/2018.

Kwale County Integrated Development Plan 2018-2022. Continuing Kwale's Transformation Together, 2018.

Lister, Sarah. "NGO Legitimacy Technical Issue or Social Construct?" Critique of Anthropology 23, no. 2 (2003): 175-192. doi:10.1177/0308275X03023002004.

Mevis, Jacques. Een Snapshot Van de Vierde Pijler in Vlaanderen. Brussels: Vierde Pijlersteunpunt, 2016.

Murunga, Godwin, Duncan Okello, and Anders Sjögren. Kenya, The Struggle for a New Constitutional Order. Zed Books: London, 2014.

Ossewaarde, Ringo, André Nijhof, and Liesbet Heyse. “Dynamics of NGO Legitimacy: How Organising Betrays Core Missions of INGOs." Public Administration and Development 28, no. 1 (2008): 42-53. doi:10.1002/pad.472. 
Plaisier, Christine, and Lau Schulpen. Mondiaal Burger Daar en Hier. Amsterdam: NCDO, 2014.

Pollet, Ignace, Rik Habraken, Lau Schulpen, and Huib Huyse. The Accidental Aid Worker: A Mapping of Citizen Initiatives for Global Solidarity in Europe. Leuven \& Nijmegen: HIVA-KU Leuven/Radboud University, 2014.

Richey, Lisa Ann, and Stefano Ponte. "New Actors and Alliances in Development." Third World Quarterly 35, no. 1 (2014): 1-21. doi:10.1080/01436597.2014.868979.

Schnable, Allison. "New American Relief and Development Organizations: Voluntarizing Global Aid." Social Problems 62, no. 2 (2015): 309-329. doi:10.1093/socpro/spv005.

Schnable, Allison. "The Era of Do-It-Yourself Aid: Possibilities and Perils." Bridge/Work 3. no. 1 (2016): Article 2.

Schulpen, Lau, Bart Loman, and Sara Kinsbergen. "Worse than Expected? A Comparative Analysis of Donor Proliferation and Aid Fragmentation." Public Administration and Development 3, no. 5 (2011): 321-339. doi:10.1002/pad.619.

Schulpen, Lau. Development in the 'Africa for Beginners.' Dutch Private Development Initiatives in Ghana and Malawi. Nijmegen: Radboud University, CIDIN, 2007.

Severino, Jean-Michel and Olivier Ray. "The End of ODA: Death and Rebirth of a Global Public Policy." Centre for Global Development - Working Paper 167, 2009.

Suchman, Mark C. "Managing Legitimacy: Strategic and Institutional Approaches." The Academy of Management Review 20, no. 3 (1995): 571-610. doi:10.2307/258788. 